Copyright (C) 2017 by Academic Publishing House Researcher

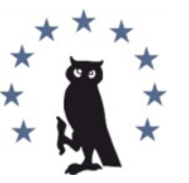

Published in the Russian Federation

European Researcher. Series A

Has been issued since 2010.

ISSN 2219-8229

E-ISSN 2224-0136

2017, 8(3): 114-121

DOI: $10.13187 /$ er.2017.3.114

www.erjournal.ru

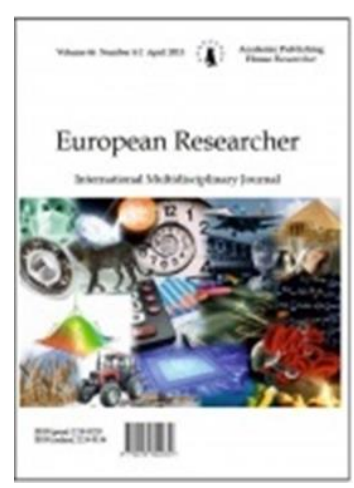

UDC 698

\title{
Contractor's Internal Factors affecting the Performance of Street Improvement Project at Sepaku-Petung Street East Borneo Province
}

\author{
Rizal Azhar a , Lalu Mulyadi a , Edi Hargono Dwi Putranto a \\ a Study Program of Civil Engineering, Concentration of Construction Management, National \\ Institute of Technology Malang, Indonesia
}

\begin{abstract}
General description of this Street Improvement Project at Sepaku-Petung Street East Borneo is located approximately 130 kilometers from Balikpapan. The road terrain is relatively poor to reach the location. The work activity is to repair the existing road that is no longer appropriate by replacing it with Rigid Pavement with the thickness of Land Concrete; it is $10 \mathrm{~cm}$ Rigid Pavement $28 \mathrm{~cm}$. Concrete and aggregate materials are provided from Sulawesi Island because it has not found suitable stones to support casting activities at Borneo Island. Iron material is provided from Samarinda City which is located approximately $100 \mathrm{~km}$ from the location. The aim of this research is to know contractor's internal factors affecting the performance of street improvement project at Sepaku-Petung Street East Borneo Province. Qualitative approach is applied in this research. This research uses questionnaires that will be distributed to each respondent so that the results will be obtained in the form of responses to the issues raised in the research. The results of this research are the factors affecting the performance of street improvement project at Sepaku-Petung Street; it is included into the category of high risk and medium risk; it is proven from the value of Communalities whose value ranges from 0.4 to 0.7 and $>0.7$. There is one factor of risks that is included into the low category because the value of Communalities is $<0.4$. The factors are the lack of time-appreciating culture (97.2\%), the poor estimation of direct construction cost (96.6\%), and the unclear payment system of the suppliers and sub-contractor (93.5\%).
\end{abstract}

Keywords: contractor, performance, project.

\section{Introduction}

The market of construction services in Indonesia is strongly influenced by the purchasing power of the people and government, which has an influence with macroeconomic developments in Indonesia. The increasing competition limits the market in Indonesia. So the condition of the construction market in Indonesia is open globally. The increasing globalization of the world economy opens up cooperation and opportunities for foreign investors to participate in various business fields in Indonesia. The growing world of construction in Indonesia is also affected by the globalization of the world economy, so that the level of competition between contractors; private, state-owned, and foreign contractors becomes very high.

Competition among these contractors is dominated by contractors of large contraction companies, (Iyer, Jha, 2006). The size of a construction service company can be potentially affected by its cost structure, and may affect the relationship between performance and adapt the basic cost 
competition mode. In order to face the free market competition, it is necessary to identify the problems that may occur in construction service companies, so that anticipatory steps can be done with various improvements to improve the quality of company performance. There are several factors that may influence and determine the success of construction service companies (contractors), the factors are internal factors, external factors and market force (Wideman, Myers 1992).

Internal factor of construction service companies (contractors) is one factor that is very important and has an influence of $42 \%$ on the success of the company (Teng, 2002). The influence of internal factors on the success of a company, especially construction service companies are dominated by Management, Organization, Human Resources, Finance, and Corporate Culture factors (Venegas, Alarcon, 1997). Internal factors of the contractor company must be managed and enhanced by the contractor itself. The ability in managing these factors is not easy, due to many changes frequently happen in the implementation of the project, (Baloi, Price, 2003). Therefore, it takes a lot of expertise in managing the project.

In most of developing countries, the increased capacity and capability of construction including improving the efficiency of the cost, timing and quality of construction work is a very important factor, (Tah, Carr, 2000). Due to the reason, by increasing the internal factors of construction companies, it will be able to improve the project cost performance better. Measuring the performance of a construction project, if it is viewed from the successful or unsuccessful work, does look simple, but it is actually a complex process, (Chua et al, 1999). Even the modern construction projects of medium size are generally diverse and involve participants consisting of designers, contractors, subcontractors, specialists, construction managers and consultants. Success for being one of the participants may be a failure for other participants, depending on the point of view between participants; each other looking at the end result.

The performance of construction project costs, in many developing countries, is a critical issue. It is mostly found that the construction project experiences cost overrun. For example, construction project in Malaysia experiences cost overrun due to two main causes, poor project cost estimates and surveyors quantity who underestimate the project costs. In practice, there are problems that may obstruct the success of a project, such as the ineffective allocation of resources, limited amount of the workers, inadequate equipment, material delays, inappropriate management of the company, cost factor, condition of bad weather, wrong working methods, bad team management and so on, so it need a good and reliable management to prevent and reduce the problems that might happen (Long et al, 2004).

A project is a temporary activity that has dimensions of time, cost, and quality in order to realize the arising ideas due to the human instinct to thrive. Suharto (1997) defines the project as a temporary activity that lasts for a limited time, with certain allocation of funding sources and is intended to carry out tasks with clearly defined targets.

Each construction project generally has a specific implementation plan and implementation schedule; when a project should begin, when it should be completed, how the project will be carried out, and how it is supplied (Kaliba et al, 2009). Planning of a project will be carried out, and how to provide the resources. The planning of a construction project always refers to the estimates that are existed at the time the development plan was created, so the problem may arise if there is a inappropriateness between the plan that has been made and its implementation, (Sawacha, 1999). So, the impact that often happens is the delay of project implementation which can be accompanied also by the increasing implementation cost of the project.

General description of this Street Improvement Project at Sepaku-Petung Street East Borneo is located approximately 130 kilometers from Balikpapan. The road terrain is relatively poor to reach the location. The work activity is to repair the existing road that is no longer appropriate by replacing it with Rigid Pavement with the thickness of Land Concrete; it is $10 \mathrm{~cm}$ Rigid Pavement $28 \mathrm{~cm}$. Concrete and aggregate materials are provided from Sulawesi Island because it has not found suitable stones to support casting activities at Borneo Island. But so far, it has not known yet, which factor causes the performance of the project is considered to be good or not good. Therefore, it is necessary to conduct a research to assess whether the Street Improvement Project is good or not.

The purpose of this research aims to know contractor's internal factors affecting the performance of street improvement project at Sepaku-Petung Street East Borneo Province. 


\section{Research Method}

Qualitative approach is applied in this research. This research uses questionnaires that will be distributed to each respondent so that the results will be obtained in the form of responses to the issues raised in the research. The population of workers, in Street Improvement Project at Sepaku-Petung Street East Borneo Province, amounted to approximately 34 people. In this research, sampling technique is conducted by Incidental Sampling method. The technique of distributing questionnaires is conducted by requesting the assistance from the staff of the contractors, involved in Street Improvement Project at Sepaku-Petung Street East Borneo Province, to distribute the questionnaire, or to share them directly to the construction workers on the project who are ready to cooperate and become the source of data. The sampling technique used in this research is Accidental Sampling. Accidental Sampling is sampling based on the fact that they appear accidentally. The project reviewed in this research is a project on Sepak-Sotek road segments at East Borneo Province. Research respondents are workers and all related persons working on the project under review. The number of samples used by researcher in this research is at least 34 people. The research instrument used is a closed questionnaire; presented in such a way form that the respondents are only to give a check on the appropriate column or place.

\section{Result and discussion}

\subsection{Simultaneous Hypothesis Testing (F test)}

To know the significant influence of independent variables at the same time over a dependent variable, $\mathrm{F}$ test is used. The results of simultaneous hypothesis testing using IBM SPSS Statistic 20 are as follows:

Table 1. Simultaneous Hypothesis Testing

\begin{tabular}{|cc|c|c|c|c|c|}
\hline & Model & Sum of Squares & df & Mean Square & F & Sig. \\
\hline \multirow{4}{*}{1} & Regression & 231.814 & 5 & 46.363 & 89.105 & $.000 \mathrm{~b}$ \\
& Residual & 14.569 & 28 & .520 & & \\
& Total & 246.382 & 33 & & & \\
\hline
\end{tabular}

Based on the output, it can be seen that the value of F-count is 89.105. The value of F-table at the $5 \%$ level and degree of freedom (df) of $k=6-1$ and the degrees of free denominator (df2) of $n-k$ $(34-5=29)$ is 2.43 . If these two values are compared, then F-count value is greater than F-table $(89.105>2.43)$, so Ho is rejected. Thus, it can be concluded that simultaneously the independent variables (management, organization, human resources, finance, and corporate culture) have a very significant influence on the dependent variable (project performance). In addition it can be seen from the significance value which is below 0.05 it is 0.000 .

\subsection{Partial Hypothesis Testing}

To know the variables affecting significantly and partially, test of regression coefficient is conducted by using t-test statistic. Determination of the test result (acceptance / rejection of Ho) can be conducted by comparing t-count with t-table or it also can be seen from the significance value. The result of partial hypothesis testing using IBM SPSS Statistict 20 is as follows: 
Table 2. Partial Hypothesis Test

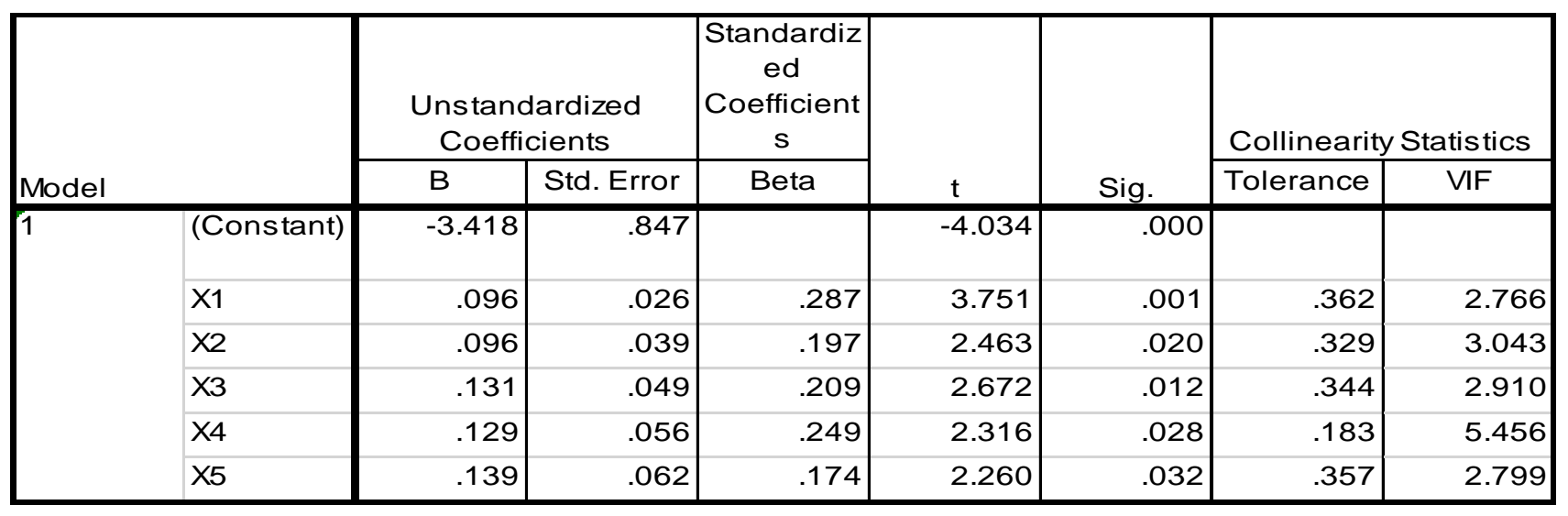

Based on the output we can see the value of $t$-table obtained by each variable. To make a conclusion whether to accept or reject Ho, it must first determine the t-table values to be used. This value depends on the degree of freedom (df) and the level of significance used. By using the $5 \%$ significance level and the df value of $\mathrm{n}-\mathrm{k}-1(34-6-1=29)$, it is obtained a t-table value of 1.699. The test results of the influence of each independent variable ( $\mathrm{X}_{1}, \mathrm{X}_{2}, \mathrm{X}_{3}, \mathrm{X}_{4}$, and $\left.\mathrm{X}_{5}\right)$ to the dependent variable $(\mathrm{Y})$ are as follows:

\section{a. Influence of Management (X1) on Project Cost Performance (Y)}

Based on the output, it is known the t-count value of 3.751. If it is compared with the t-table value of 1.699 then the $t$-count obtained is much greater than the value of $t$-table. So Ho is rejected. Thus, it can be concluded that management variable significantly influences the project cost performance. It can also be seen from the significance value of X1 which is smaller than 0.05 i.e. $0.001<0.05$.

\section{b. Influence of Organization (X2) on Project Cost Performance (Y)}

Based on the output, it is known the t-count value of 2.463. If it is compared with the t-table value of 1.699 then the $t$-count obtained is much greater than the value of t-table. So Ho is rejected. Thus, it can be concluded that organization variable significantly influences the project cost performance. It can also be seen from the significance value of $\mathrm{X} 2$ which is smaller than 0.05 i.e. $0.020<0.05$.

\section{c. Influence of Human Resources (X3) on Project Cost Performance (Y)}

Based on the output, it is known the t-count value of 2.672. If it is compared with the t-table value of 1.699 then the $t$-count obtained is much greater than the value of $t$-table. So Ho is rejected. Thus, it can be concluded that human resources variable significantly influences the project cost performance. It can also be seen from the significance value of $\mathrm{X}_{3}$ which is smaller than 0.05 i.e. $0.012<0.05$

\section{d. Influence of Finance (X4) on Project Cost Performance (Y)}

Based on the output, it is known the t-count value of 2.316. If it is compared with the t-table value of 1.699 then the $t$-count obtained is much greater than the value of $t$-table. So Ho is rejected. Thus, it can be concluded that finance variable significantly influences the project cost performance. It can also be seen from the significance value of $\mathrm{X} 4$ which is smaller than 0.05 i.e. $0.028<0.05$.

\section{e. The Influence of Corporate Culture (X5) on Project Cost Performance (Y)}

Based on the output, it is known the t-count value of 2.260. If it is compared with the t-table value of 1.699 then the $t$-count obtained is much greater than the value of t-table. So Ho is rejected. Thus, it can be concluded that corporate culture variable significantly influences the project cost 
performance. It can also be seen from the significance value of $\mathrm{X}_{5}$ which is smaller than 0.05 i.e. $0.032<0.05$.

\subsection{Coefficient of Determination}

The coefficient of determination essentially measures how far the model's ability to explain variations of variables. The coefficient of determination is used because it can explain the goodness of the regression model in the dependent variable. The higher the coefficient of determination the better the ability of the independent variable in explaining the dependent variable. The coefficient of determination is between zero and one. The small value of R2 means that the ability of the independent variables in explaining the variation of the dependent variable is very limited. A value close to one means the independent variables provide almost all the information needed to predict the variation of the dependent variable. By using IBM SPSS Statistic 20, it is obtained coefficient of determination as follows:

Table 3. Coefficient of Determination

\begin{tabular}{|c|c|c|c|c|c|}
\hline Model & $\mathrm{R}$ & R Square & Adjusted R Square & $\begin{array}{c}\text { Std. Error of the } \\
\text { Estimate }\end{array}$ & Durbin-Watson \\
\hline 1 & $.970^{\mathrm{a}}$ & .941 & .930 & .72133 & 1.929 \\
\hline
\end{tabular}

From the output result of SPSS, it can be seen that the coefficient of determination or R Square is 0.941 or $94.1 \%$. It shows that the variables studied by management (X1), organization (X2), human resources $\left(\mathrm{X}_{3}\right)$, finance $\left(\mathrm{X}_{4}\right)$, corporate culture $\left(\mathrm{X}_{5}\right)$ give influence to project cost performance $(\mathrm{Y})$; it equals to $94,1 \%$, while the rest is influenced by variable which is not investigated (interfering variable).

3.4. Strategy to Minimize contractor's internal factors affecting the performance of street improvement project at Sepaku-Petung Street East Borneo Province; affecting the performance of street improvement project at Sepaku-Petung Street East Borneo Province

Factors in each variable have significantly influenced on the performance of a project, it is proved by the value of T-count and F-count of each variable is smaller than 0.05. In addition, from the factor analysis, it can be seen the percentage of the most dominant factor to the lowest of each variable.

\subsection{Corporate Culture Variable $\left(\mathrm{X}_{5}\right)$}

From the finance variables, it can be seen the percentage of factors from the most dominant to the smallest, as shown in the following table:

Table 4. Percentage of Factor $\mathrm{X}_{5}$

\begin{tabular}{|c|c|}
\hline & Component \\
\cline { 2 - 2 } & 1 \\
\hline (X5.3) Lack of implementation of information technology systems & .709 \\
(X5.5) Unacceptable company systems and procedures & .657 \\
\hline
\end{tabular}

The strategy to minimize each of the factors that exist in the corporate culture variable is by the development of information technology systems should always be improved in accordance with technological changes that are growing. The systems and procedures used must be applicable and can offer high project cost offerings. 


\subsection{Finance Variable $\left(\mathrm{X}_{3}\right)$}

From the finance variable, it can be seen the percentage of factors from the most dominant to the smallest, as shown in the following table:

Table 5. Percentage of Factor $X_{3}$

\begin{tabular}{|c|c|}
\hline & Component \\
\cline { 2 - 2 }$\left(\mathrm{X}_{3}\right.$.4) Absence of Specific Training on Human Resources & 1 \\
\hline$\left(\mathrm{X}_{3.5}\right)$ Incorrect placement of Human Resources & .844 \\
& .914 \\
\hline
\end{tabular}

The strategy to minimize the risk for each factor in Human Resource variable is to conduct training for each project of Human Resource in order to improve the quality of the project of Human Resource. Then the human resources used must be qualified and in accordance with the ability in their respective fields.

\subsection{Human Resource Variable (X4)}

From the Human Resource variable, it can be seen the percentage of factors from the most dominant to the smallest, as shown in the following table:

Table 6. Percentage Factor $\mathrm{X}_{4}$

\begin{tabular}{|l|c|}
\hline & Component \\
\cline { 2 - 2 } & 1 \\
\hline (X4.3) Error in work capital calculation & .825 \\
(X4.4) Improper cost control (cash flow) & .868 \\
(X4.6) Unclear payment system of suppliers and sub-con & .900 \\
\hline
\end{tabular}

The strategy to minimize project cost swelling is to perform efficient labor cost calculations. On the street project, it is conducted by optimizing the cost factor of the worker with the framework of the process of project work. The data used in this research are data of direct cost budget plan and realization of project direct cost including material cost, worker cost, tool cost, sub-contractor cost and field overhead cost. The cost modeling method is considered a viable method on the basis of an assumption. The research method is conducted by using the project cost budget plan data and the realization of project cost. Both inputs are used to obtain cost performance modeling, and then optimization is made to model the performance of this project. This research is conducted to determine which factors are the most dominant in the cost performance of a project so that the company is able to set the strategy to optimize the cost of the work of a project.

\subsection{Organization Variable (X2)}

From organization variable, it can be seen the percentage of factors from the most dominant to the smallest, as shown in the following table: 
Table 7. Percentage of Factor X2

\begin{tabular}{|l|c|}
\hline & Component \\
\cline { 2 - 2 } & 1 \\
\hline (X2.7) Poor coordination between general contractor and sub-contractor & .733 \\
(X2.8) Poor coordination between general contractor and owner & .701 \\
\hline
\end{tabular}

The strategy to minimize the risk of each of the factors that exist in the organization variables is to create a unique and different project from the project in general, where the running project looks like a project that requires high technical knowledge. In addition, decision-making should be promptly decided. Project formulation at the time of planning should be made ahead of time and should not made in a short time. Coordination between general contractor and sub-contractor, contract management, coordination between general contractor and owner, and coordination between the design team and the General Contractor should be made as possible in order to have the same mission and objectives. In a project, they should not blame each other. So all parties should be able to support and help each other.

\subsection{Management Variable (X1)}

From the management variable, it can be seen the percentage of factors from the most dominant to the smallest, as shown in the following table:

Table 8. Percentage of Factor $\mathrm{X} 1$

\begin{tabular}{|c|c|}
\hline & Component \\
\cline { 2 - 2 } & 1 \\
\hline (X1.11) Incompetent Project Management Team & .700 \\
(X1.14) Errors in Preparing/Planning Productivity Tools \& Workers & .782 \\
\hline
\end{tabular}

Table 9. Strategies that Must be Applied

\begin{tabular}{|l|l|}
\hline \multicolumn{1}{|c|}{ Variables } \\
$\begin{array}{l}\text { Corporate Culture } \\
\text { (X) }\end{array}$ & $\begin{array}{l}\text { Raises more efficient and better informative technology systems } \\
\text { Improving company procedures to become more applicable }\end{array}$ \\
\hline $\begin{array}{l}\text { Human } \\
\text { Resources }\end{array}$ & $\begin{array}{l}\text { Conducting trainings so that the skills of the human resources is increasing } \\
\text { Put the human resources in the right place }\end{array}$ \\
\hline Finance & $\begin{array}{l}\text { Calculate and analyze the factors that affect the high working capital, then } \\
\text { Improve efficiency in planning the working capital } \\
\text { Improve Cash Flow control } \\
\text { Seeking innovative ways about 3rd party payment systems }\end{array}$ \\
\hline Organization & $\begin{array}{l}\text { Look for ways and apply how to coordinate with third parties, Apply good } \\
\text { coordination between General Contractor and Owner,train the management } \\
\text { team to be more competent, or replace with a better team } \\
\text { Apply good coordination between General Contractor and Owner }\end{array}$ \\
$(\mathrm{X} 2)$ & $\begin{array}{l}\text { Train the management team to be more competent, or replace with a better } \\
\text { team } \\
\text { Planning for better tool and power productivity so that productivity is higher }\end{array}$ \\
\hline Management \\
(X1)
\end{tabular}

The strategy to minimize the risk of management is the method used in project management. In addition, it should manage the equipment needed for the construction project appropriately, because the equipment used in the project differs according to the project being worked on. The formation of a project team must also use a workforce that is really competent in their field so that the project can be in accordance with the desired target. Every element in the project should know and 
understand the planning techniques and planning tools used in the project. Monitoring in the project should always be conducted to determine the increase or shortcomings that occur in the project. The planning used in the project should be exactly in line with the project targets being worked on.

\section{Conclusion}

Based on the research result and the data analysis, then it is obtained the following conclusions:

1. The risk factors contained in the independent variables have an influence on the performance of the project implementation of street improvement project in East Kalimantan Province, it is proved by the significance value of $<0.05$. Factors affecting project performance in the implementation of the street improvement project are included into the high risk and medium risk category, it is proven by the value of Communalities whose value ranges from 0.4 to 0.7 and > 0.7. There is one risk factor that includes into the low category because the value of Communalities is < 0.4. Those factors are the lack of time-appreciating culture (97.2\%), poor estimation of direct construction cost (96.6\%), and unclear payment system from the supplier and sub-con (93.5\%)

2. The most dominant factor affecting the performance on the street improvement project at Sepaku-Petung Street is Corporate Culture factor with the largest constant value based on F Test

3. Strategies for improving Performance in Street Improvement Project, such as:

a. $\quad$ Raising the information system more efficiently and better.

b. Placing Human Resource in the right place based on its ability.

c. Looking for innovative ways about third party payment systems.

d. Finding ways and apply how to coordinate with third parties well.

e. Planning for better equipment and power productivity so that productivity is higher.

\section{References}

Baloi, Price, 2003 - Baloi, D., Price, A. D. (2003). Modelling global risk factors affecting construction cost performance. International journal of project management, 21(4), 261-269.

Chua et al., 1999 - Chua, D. K. H., Kog, Y. C., Loh, P. K. (1999). Critical success factors for different project objectives. Journal of construction engineering and management, 125(3), 142-150.

Dissanayaka, S. M., Kumaraswamy, 1999 - Dissanayaka, S. M., Kumaraswamy, M. M. (1999). Evaluation of factors affecting time and cost performance in Hong Kong building projects. Engineering Construction and Architectural Management, 6(3), 287-298.

Iyer, Jha, 2006 - Iyer, K. C., Jha, K. N. (2006). Critical factors affecting schedule performance: Evidence from Indian construction projects. Journal of construction engineering and management, 132(8), 871-881.

Kaliba et al., 2009 - Kaliba, C., Muya, M., Mumba, K. (2009). Cost escalation and schedule delays in road construction projects in Zambia. International Journal of Project Management, 27(5), 522-531.

Long et al., 2004 - Long, N. D., Ogunlana, S., Quang, T., Lam, K. C. (2004). Large construction projects in developing countries: a case study from Vietnam. International Journal of project management, 22(7), 553-561.

Sawacha et al., 1999 - Sawacha, E., Naoum, S., Fong, D. (1999). Factors affecting safety performance on construction sites. International journal of project management, 17(5), 309-315.

Soeharto, Iman, 1997 - Soeharto, Iman, (1997), Manajemen Proyek, Erlangga, Jakarta

Tah, Carr, 2000 - Tah, J. H. M., Carr, V. (2000). A proposal for construction project risk assessment using fuzzy logic. Construction Management \& Economics, 18(4), 491-500.

Teng, 2002 - Teng, M. (2002). Corporate Turnaround. Prentice-Hall, Inc, Alexandra Road, Singapore.

Venegas, Alarcon, 1997 - Venegas, P., Alarcon, L.F. (1997). Selecting long-term strategies for construction firms. Construction management and economics journal.

Wideman, Myers, 1992 - Wideman, R. E., Myers R. H. (1992). Project and Program Risk Management. A Guide to Managing Project Risk and Opportunities, Project Management Institute. Pennysylvania. 